\title{
TYPOLOGY OF THE TOOLS OF EC COMMUNICATIONS REGULATION
}

\author{
Mira Burri-Nenova*
}

\section{INTRODUCTION}

In the economic and legal literature, there is no fixed and all-encompassing definition of regulation. ${ }^{1}$ For the purposes of this work, the generic definition given by the Encyclopaedia of Law and Economics will be used and regulation will be understood broadly as the "employment of legal instruments for the implementation of socio-economic policy objectives". ${ }^{2}$ Characteristic of these legal instruments is that individuals, companies or organisations can be compelled by the government (or other authority) to comply with the prescribed behaviour under penalty of sanctions. ${ }^{3}$

In the above sense, through the application of diverse legal instruments, governments regulate industries in a variety of ways in an attempt to achieve a number of different objectives. Few industries have been, amongst the others, selected for a special treatment because of their unique importance to society. As already discussed in Part One, telecommunications are precisely such an industry. They have always been considered of special interest, at least to governments, if not consistently to the general public as well. Viewed initially as important to national security and defence, telecommunications were appended in the majority of countries, as the acronym PTT (Post, Telegraph and Telephone) shows, to the established postal system and followed the standard natural monopoly regulatory model.

When one looks back at the history of (tele)communications regulation, one can discern that almost all countries made a specific policy choice as to how telegraph and telephone should be treated when these new services were introduced and considered them primarily as governmental social services, rather than as services to be supplied by private businesses in normal markets. The comprehensive monopoly and quasi-monopoly regulation of

\footnotetext{
* Mira Burri-Nenova is a senior research fellow at the World Trade Institute at the University of Bern, Switzerland and an alternate leader of the research project "eDiversity: The Legal Protection of Cultural Diversity in a Digital Networked Environment", which is part of the Swiss National Centre of Competence in Research 'Trade Regulation'. Contact at mira.burri@wti.org. The present work is an abridged chapter of the book by Mira Burri-Nenova, EC Electronic Communications and Competition Law, London: Cameron May, 2007.

1 JohAn Den Hertog, "General Theories of Regulation" in BOUdewijn BoucKaert and Gerrit De GeEst (eds.), Encyclopaedia of Law and Economics, Cheltenham, UK: Edward Elgar Publishing, 2000, pp. 223-270, at p. 223.

2 Johan Den Hertog, ibid. See also AnthOny I. Ogus, Regulation: Legal Form and Economic Theory, Oxford: Clarendon Press, 1994, at pp. 1 et seq.

3 JOHAN DEN HERTOG, ibid.
} 
telecommunications that developed accordingly in the course of a century followed the public utility principle established as early as in 1877 in the case of Munn v. Illinois, where the right of the government to regulate was tested. The US Supreme Court stated therein:

"When, therefore, one devotes his property to a use in which the public has an interest, he, in effect, grants to the public an interest in that case, and must submit to be controlled by the public for the common good, to the extent of the interest he has thus created". ${ }^{4}$

Today, as already discussed, these views have changed and the public utility monopolistic status of communications is largely rendered part of the regulatory history of the sector. It is, nevertheless, significant for the purposes of this Part to acknowledge the fact that the telecommunications industry has always had a special regulatory status, has always been and still is, a heavily regulated sector. ${ }^{5}$ The nature of the regulatory instruments and their focus have however changed due to the radical changes that occurred in the industry itself and in the economic perceptions of it.

Interestingly, despite the long existing special regulatory status of telecommunications, it is only recently that we speak of telecommunications law as such. Indeed, "at the turn of the millennium it is interesting to reflect that the current telecommunications regulatory regime in the [EC Member States] and those of many other countries came into existence less than twenty years ago". ${ }^{6}$ This recently developed branch of law is a work in progress and its attempt to follow the dynamic drive of the communications industry poses multiple regulatory challenges that are to be examined in the course of this Part and Part Three. But first, let us concentrate on the tools that could (or not) meet these challenges.

\section{The COMMUNiCATIONS RegUlATION TOOLKIT}

As already mentioned and as will be further elaborated on in this Part, the regulatory tools applied to communications markets could be broadly identified as competition law and sector specific rules. Throughout the history of the sector, they have been applied with various degrees of intensity, the visible line of development being from sectoral regulation only, through introduction of competition and multiple hybrid models to (hypothetically) pure competition law supervision in the future. This line of development, as well as the exact characteristics of each type of rules, differ to a certain extent from country to country but one could still discern this evolutionary pattern. The following examination of competition and sectoral rules is based exclusively on the European Community's experience but since it will focus on the main characteristics of the instruments, certain level of abstraction will be

${ }^{4}$ Munn v. Illinois, 94 US 113 (1877), at 126, as quoted by WILliam H. Melody, "Policy Objectives and Models of Regulation“ in William. H. Melody (ed.), Telecom Reform: Principles, Policies and Regulatory Practices, Lyngby: Technical University of Denmark, 1997, pp. 11- 24, at p. 13 (emphasis added).

5 JeAn-Jacques LafFont and Jean TIROLE, Competition in Telecommunications: Munich Lectures in Economics, Cambridge, MA: MIT Press, 2000, at p. 16.

${ }^{6}$ DAVID GILlies and Roger Marshall, Telecommunications Law, Vol. 1, 2nd edition, London: Butterworths LexisNexis, 2003, at p. 1 . 
achieved and the arguments given will also hold true in most other contexts. ${ }^{7}$ The next Sections will present the existing regulatory options, i.e. competition law and sectoral regulation as distinct tools of regulatory intervention and will seek to assess their regulatory potential. The analysis will be abstract and by reducing the complexity of the instruments will try to pinpoint their most essential characteristics.

\subsection{COMPETITION LAW}

Competition laws refer generally to legislation, regulations and Court decisions that relate either to (i) agreements between firms that restrict competition; (ii) to abuse of dominant position by a firm or (iii) to firms merging together. The rules established by these laws are intended to ensure that the competitive process is not hindered through the creation of dominance or agreements between competitors that prevent, restrict or distort competition. The term competition policy, however, has a broader meaning and refers to a set of measures and instruments used by governments that determine the overall conditions of competition that are likely to be met in specific markets. As such, competition law is a subset of competition policy. The broader package of instruments influencing competition policy could include privatisation, deregulation, liberalisation, foreign investment policy and subsidies. Viewed in this way, domestic competition policy is also affected by regional and international agreements. Competition policy may thus even lead to a restriction of competition in cases where it is argued that this entails greater efficiency. In that sense, competition policy can also be seen as a political process, where multiple stakeholders interact (both in government and in the various industries). On the business side, competition policy could equally be identified as a social and economic process. ${ }^{8}$ The purpose of the paragraphs that follow is to concentrate exclusively on the competition law rules as instruments of regulation and will attempt to reveal some of their typical features.

At European Community level, the main general competition rules are contained in Article 81 EC prohibiting anti-competitive agreements, Article 82 EC prohibiting abuse of dominant position, Article 86 EC regarding undertakings with special or exclusive rights, Article 87 EC on state aids and the Merger Regulation. A specific feature of EC competition law is that, in contrast to national competition systems and in particular to US antitrust, where the law is to be found in diverse or codified statutes, European antitrust rules are contained in a Treaty..$^{9}$ As part of the EC Treaty, ${ }^{10}$ the European competition rules are part of the whole system

\footnotetext{
7 The same approach has been used by Paul Nihoul and Peter Rodford in their key work on EU electronic communications law. For their argumentation in that regard, see PAUL NiHOUL and PETER RODFORD, EU Electronic Communications Law, Oxford: Oxford University Press, 2004, at para. 1.11.

8 P.H. LONGSTAfF, "The Puzzle of Competition in the Communications Sector: Can Complex Systems be Regulated or Managed?", Program on Information Resources Policy, Harvard University, July 2003, available at $<$ http://www.pirp.harvard.edu>, at p. 10.

${ }^{9}$ Before the adoption of a specific merger control Regulation (currently Council Regulation (EC) 139/2004 of 20 January 2004 on the control of concentrations between undertakings, OJ L 24/1, 29 January 2004), merger rules were based on Article 82 EC. See Case 6/72 Europemballage and Continental Can v. Commission [1973] ECR 215, [1973] CMLR 1999.

${ }^{10}$ Initially in the Treaty establishing the European Economic Community, Rome, 25 March 1957. Now in the Treaty establishing the European Community, consolidated version, OJ C 325/33, 24 December 2002. The provisions on competition form
} 
establishing what was initially called the European Economic Community (now European Community ${ }^{11}$ ) and thus serve to the achievement of the internal market along with the other Treaty provisions. The EC competition rules could thus be perceived as one of the instruments of negative integration together with the four freedoms, ${ }^{12}$ the principle of mutual recognition and the elimination of restraints of trade and competition. ${ }^{13}$ Being part of the overall EC policies' structure, competition law and its implementation are accordingly influenced (to a different extent) by the rest of the Community's policies. ${ }^{14}$ Often have the Community institutions interpreted the competition provisions in view not only of the particular case but also teleologically, in the broader framework of Articles 2 and 3(1)(g) of the EC Treaty. ${ }^{15}$

Another particular characteristic of EC competition law, being established at supra-national level, is that its substantive norms are directed both at the public and private undertakings, as well as at the Member States. Consequently, the competition rules provide a legal instrument that is not (or at least less) reliant, in comparison to EC secondary legislation, on Member States for application and which can equally be applied against them by virtue of Article 10 EC. ${ }^{16}$

For the sake of the comparison between competition rules and sector specific ones, the focus will be exclusively on Article 82 EC since it applies to the unilateral conduct of undertakings and not to agreements, decisions or concerted practices of undertakings, where concurrence of wills is needed. The latter, although clearly an integral part of competition law, bears less significance to our discussion of antitrust as an instrument of regulatory intervention directed at market power and particularly, in the context of comparison with sectoral rules. Logically, in the context of this work, the examples for both antitrust and sector specific rules' application will stem from the communications sector.

Any guidelines that clarify the implementation of general competition rules, where these guidelines apply equally to all economic sectors will be included in the definition of EC competition law (such as, for instance, the Commission Notice on the definition of the

also an integral part of the future Constitution of the European Union. See Treaty establishing a Constitution for Europe (provisional consolidated version, OJ C 310/1, 16 December 2004), Part III, Articles III-161 to III-166. On the development of EC competition law, see e.g. PIET JAN SLOT, “A View from the Mountain: 40 Years of Developments in EC Competition Law" (2004) Common Market Law Review, Vol. 41, pp. 443-473.

${ }_{11}$ Ibid. Renamed "European Community" with the Treaty of Maastricht (OJ C 191/1, 29 July 1992). See Treaty establishing the European Community, consolidated version 1992, OJ C 224/1, 31 August 1992.

${ }^{12}$ That is, the free movement of goods, services, persons and capital. See Articles 23-31 and 39-60 of the EC Treaty.

${ }^{13}$ In contrast to positive integration, under which category harmonisation and liberalisation rules fall. On the relation positive/negative integration, see FRITZ W. SCHARPF, Governing in Europe: Effective and Democratic?, Oxford: Oxford University Press, 1999, at Chapter 2.

14 "[Competition policy] [...] is not managed in a sort of vacuum [...] but in relation to the other policies of the EEC Treaty conducted by the European Commission [...] [and] can be influenced by other policies such as industrial and agricultural policy, research policy, transport policy, environment policy, consumer protection policy". See JEAN-FRANÇOIS VERSTRYNGE, "Current Anti-Trust Policy Issues in the EEC: Some Reflections on the Second Generation of Competition Policy“ (1984) Fordham Corporate Law Institute (Annual Proceedings), pp. 673 et seq., at p. 678, as quoted by MEL KENNY, The Transformation of Public and Private EC Competition Law, Berne: Staempfli Publishers, 2002, at p. 31.

${ }^{15}$ See e.g. Cases C-68/94 and 30/95 France v. Commission [1998] ECR I-1375, [1998] 4 CMLR 829, at paras 169 et seq.

${ }^{16}$ ANTONIO BAVASSO, Communications in EU Antitrust Law, The Hague/London/Boston: Kluwer Law International, 2003, at p. 8. See also RichARD WHISH, Competition Law, $5^{\text {th }}$ edition, London: Butterworths LexisNexis, 2003, at pp. 212 et seq. 
relevant market for the purposes of Community competition law). ${ }^{17}$ The liberalisation Directives although adopted on the basis of Article 86(3) EC (i.e. primary antitrust provision) will not fall under the competition law category used for the comparison, since they introduce general obligations regarding telecommunications and in that quality come close to sectoral rules. The ONP (Open Network Provision) harmonisation Directives, adopted on the basis of Article 95 EC will definitely be considered a part of the sectoral regulation.

\subsection{SECTOR SPECIFIC REGULATION}

The body of law that is referred to as sector specific regulation consists of rules and instruments, which were adopted in view of the specific issues appearing on specific markets, i.e. in our case, in view of the specificities of the communications markets. ${ }^{18}$ "As a result, they apply only to [...] [the latter], although they provide a model for the establishment of rules regarding other, but similar, sectors"19 (e.g. for other network industries, such as electricity, post or gas). The telecommunications industry being perceived as a natural monopoly was regulated primarily by sector specific rules before the liberalisation process. Sectoral rules were used as a surrogate for the pressure that competitive forces would exert to deliver economic efficiency, and in effect mimic the market. The regulatory framework as such was rather simple and its administration easy since the monopoly supplier provided a single focal point for effective implementation of government objectives. The overall results of this "mimicking" were, nevertheless, fairly poor.

In the European Community context, sector specific rules constitute secondary legislation, i.e. rules not contained explicitly in the Treaty and deriving their legitimacy from the legislative mandate of the Communities. They are primarily adopted on the basis of Article 95 EC as a means of harmonisation (i.e. positive integration) and in the form of Directives ${ }^{20}$ that prescribe certain goals and parameters of the instruments for the achievement of these goals. Member States are required to adapt accordingly their national legislation, which normally involves the adoption, amendment or withdrawal of laws, regulations and/or administrative provisions. ${ }^{21}$ In that sense, it should be made clear that when one talks about EC

${ }^{17}$ EUROPEAN COMMISSION, Notice on the definition of the relevant market for the purposes of Community competition law, OJ C 372/5, 9 December 1997.

${ }^{18}$ For an excellent overview of diverse national communications laws and regulations, see COLIN D. LONG (general ed.), Global Telecommunications Law and Practice, London: Sweet and Maxwell, 2000-2004. See also Jos DuMORTIER (ed.), Cyber Law, Vol. 1 and 2 in Roger BLANPAIN (general ed.), International Encyclopaedia of Laws, The Hague/London/Boston: Kluwer Law International, 2005.

19 PAUl NiHOUl and Peter RODFORD, supra note 7, at para. 1.46.

${ }^{20}$ Although the typical instrument of regulation in European telecommunications is the Directive, other binding instruments, depending on the purpose, can be embodied in decisions and/or regulations. The former can be directed at other EC institutions, Member States, physical and legal persons and are binding to their addressees only (see e.g. Decision 676/2002/EC on a regulatory framework for radio spectrum policy in the European Community, OJ L 108/1, 24 April 2002). Regulations, on the other hand, unlike Directives, are directly applicable in the Member States and become automatically part of their legal systems without any further national transformation act (see e.g. Regulation 2887/2000/EC of the European Parliament and of the Council of 18 December 2000 on unbundled access to the local loop, OJ L 336/4, 30 December 2000). On the effect of the Community instruments, see generally Article 249 EC.

21 On harmonisation as a purposive instrument for the realisation of market integration, see PIET JAN SLOT, "Harmonisation" (1996) European Law Review, Vol. 21, pp. 378-396; CATHERINE BARNARD, The Substantive Law of the European 
communications law, besides the rules created at the Community level, there are in reality a variety of pieces of national legislation implementing those rules. Within the comparison between competition rules and sector specific regulation that follows, sometimes a distinction will be made between the "old" communications regulations (under the 1998 framework) and under the "new" sectoral rules (under the 2002 and the 2007 packages) since the latter often converge with the competition law in methodology and assessment and in that sense diverge from what may be construed as "classical" sectoral regulation.

\subsection{COMPARISON OF THE REgUlATORY TOOLS}

In order to facilitate the comparison between competition law and sector specific regulation as instruments of intervention, the comparison will be conducted according to simplified sets of opposite characteristics. ${ }^{22}$ Each pair will be consecutively elaborated upon in order to establish the pros and cons these characteristics might have when projected onto the dynamic environment of electronic communications. To achieve visibility of the advantages or disadvantages of both instruments the contrast between regulation and antitrust will be sharpened, although, in truth, as we shall see below, the real boundaries are not as manifest.

Figure One: Key Features of General Competition Rules and Sector Specific REGULATION

\begin{tabular}{|l|l|}
\hline GENERAL COMPETITION RULES & SECTOR SPECIFIC RULES \\
\hline General and abstract framework & Tailored rules \\
\hline Reactive in nature & Pro-active nature \\
\hline Designed to protect competition & Power to promote or restrict competition \\
\hline One-off interventions & Long-term perspective \\
\hline Narrowly focused objectives & Broad range of objectives \\
\hline Limited instruments & Broad range of instruments \\
\hline Antitrust expertise & Communications industry expertise \\
\hline
\end{tabular}

SOURCE: THEON VAN DIJK ${ }^{23}$

Union, Oxford: Oxford University Press, 2004, at pp. 493 et seq. On the conceptual pair positive/negative integration and the related institutional conditions, see FRITZ W. SCHARPF, supra note 13, at Chapter 2.

${ }^{22}$ See infra Figure One. These characteristics are framed as opposite only for the sake of the comparison. The two sets of instruments are essentially much more versatile in nature and application. The comparison follows an outline suggested by THEON VAN DIJK, "General or Specific Competition Rules for Network Utilities?" (2001) Journal of Network Industries, Vol. 2, pp.93-111. For a different strategy in comparing sectoral and competition rules, see DAMIEN GERADIN and MICHEL KERF, Controlling Market Power in Telecommunications, Oxford: Oxford University Press, 2003, at pp. 18-23. See also EUROPEAN COMMISsION, Liberalisation of Network Industries: Economic Implications and Main Policy Issues, Report of the DG for Economic and Financial Affairs No 4, Brussels, 1999, at pp. 36 et seq. and pp. 123 et seq.

${ }^{23}$ Based on THEON VAN DIJK, ibid. at p. 95. The table is used as a model although the argumentation based upon it does not necessarily follow Theon Van Dijk's reasoning. For a different graphic representation of the specific characteristics of competition 


\subsubsection{GENERAL AND ABSTRACT VERSUS TAILORED RULES}

Generic competition rules are normally set out in broad and abstract terms. In the European context, they are contained in the EC Treaty in no more than two core provisions. Mel Kenny notes in that regard that, "...the basic provisions of competition law share the terse formulation and indeterminacy characteristic of a traité cadre: Articles 81 and 82 only chart the substantive principles for private undertakings when conduct affects trade...". ${ }^{4}$ The existing formulae are thus designed and able to capture anti-competitive practices in all sectors of the economy (exceptions being allowed only under restrictive conditions). ${ }^{25}$ The concepts used, such as undertaking, dominance, abuse, etc. can apply across the board to all industries and with the development of the Community law and practice have received a certain unified meaning. In that sense, the Treaty Articles give the basis and the initial shape of the rules that have been gradually filled with content by the practice of the European Courts, further shaping the law and reaffirming the basis. Theon van Dijk argues in that regard that given the broad terms, the application of these general competition rules is "inevitably less predictable, exposing firms to more regulatory risk" ${ }^{26}$ In fact, this is true only to a certain extent. One could argue that the basis of almost fifty years legal practice and the intensified alignment of antitrust with economic theory are steady and coherent enough to exclude "surprising" developments and decisions of the Courts. ${ }^{27}$

As far as network industries are concerned, such as notably, communications, there could be, nonetheless, possibilities for uncertainty stemming from reliance on competition rules. Without detailed regulations to follow, the undertakings would need to judge what level of prices would be regarded as abusive by the authorities. This would involve an assessment of the competition authority's likely view of "reasonable" network access prices, which are notoriously difficult to calculate considering the very large fixed costs in network industries. ${ }^{28}$ In that sense, the 2002 Community regime for electronic communications networks and services provides, as we shall see below, a reliable mechanism for transition to competition rules since the undertakings will have the possibility to see what the approach of the regulatory authorities with regard to imposition of specific obligations is and gather experience.

What the broadly formulated competition legal provisions definitely allow is flexibility. Since there is no explicit focus on a certain technology or certain constellation of facts, new

and sectoral rules, see the World Bank, Telecommunications Regulation Handbook, Module 5: Competition Policy, Washington, DC: The World Bank, 2000, at p. 5-6.

${ }^{24}$ MeL KENNY, supra note 14, at p. 29 (emphasis added).

${ }^{25}$ In the EC, such exceptions applied before to the public utility sectors (including telecommunications) and are still applicable e.g. to agriculture (see Articles 32 to 38 EC). See also RICHARD WHISH, supra note 16, at pp. 920-924 with references to the relevant literature at p. 20, footnote 6 .

26 THEON VAN DIJK, supra note 22, at p. 95.

${ }^{27}$ On the development and transformation of EC competition law, see MEL KENNY, supra note 14, especially Chapters Two and Four.

${ }^{28}$ See Jean-Jacques Laffont and Jean TiROle, "Access Pricing and Competition" (1994) European Economic Review, Vol. 38, pp. 1673-1710, as referred to by THEON VAN DIJK, supra note 22, at p. 96. See also OECD, Access Pricing in Telecommunications, Paris: OECD Publishing, 2004. 
situations can be subsumed under the general rule. The rules are thus not bound by the policy of the particular period (or at least, less than sectoral regulation) and could serve in the long term to the achievement and sustainment of effective competition.

The sector specific rules, on the other hand, are "by definition designed to apply in one unique context [...] [and] can be shaped to take account of particular technical and economic characteristics". ${ }^{29}$ Consequently, they allow for more precise regulatory intervention and could address specific problems with specifically designed for the purpose tools. The affected undertakings could also have a clear understanding of the parameters of this regulatory intervention and act accordingly.

Yet, in a sector as dynamically changing as electronic communications, this very specificity of the sectoral tools would prevent them from following the technological and market developments and render them outdated within a relatively short period of time. A new market situation would naturally call for a new regulation. The frequent amendments of the sector specific regime might then interfere with the legal expectations of the undertakings and seriously harm their long-term market strategies and the overall development of the sector.

In addition, the change of the regulatory framework might not be as quick as necessary to address the changed reality. Considering that Article 86(3) EC is no longer available as a legal basis for adopting Directives, ${ }^{30}$ whereby the Commission acts alone, the standard Article 95 EC co-decision procedure ${ }^{31}$ might be prohibitively long. In that sense, it seems that the clarity of the specific rules has a substantial downside in the lack of flexibility towards new situations. The latter reasoning was inter alia one of rationales behind the reform undertaken in EC telecommunications regulation. As will be discussed below, what is sought within the new regime is a regulatory potential to handle new developments within a coherent framework.

A third point that could be made with regard to the pair "general and abstract competition rules $v$. tailored sectoral rules" concerns the implementation of those. It is quite understandable that the specific rules being clearly defined and generally excluding interpretation of concepts and/or facts or further analysis are easier to implement. ${ }^{32}$ Moreover, in that context, they are also faster to implement and thus allow for addressing in a swift manner urgent issues. The competition rules being broadly defined give substantial room for interpretation and one could, applying the same rules in different contexts, reach different conclusions. Competition rules require generally in-depth analysis, including analysis of past facts. This renders them far more difficult to apply and demands more time and resources. What is, nonetheless, achieved through the competition law analysis is also a more complete picture of the situations and relationships at issue. Such a complete picture is of great significance in the electronic communications sector where the relationships between

\footnotetext{
29 THEON VAN DIJK, ibid. at p. 95.

${ }^{30}$ For extensive analysis on the use of Article 86(3) EC in a liberalised environment, see PIERRE LAROUCHE, Competition Law and Regulation in European Telecommunications, Oxford/Portland, Oregon: Hart Publishing, 2000, at pp. 91-107.

31 Article 95 EC is the standard harmonisation legal basis. The procedure for adoption of measures under it is co-decision, involving the Council and the European Parliament. See generally Article 251 EC.

${ }^{32}$ Having in mind classical sector specific regulation such as the ONP rules.
} 
undertakings and/or markets can be particularly complex, especially against the background of convergence and the importance of emerging markets. The implementation of competition rules in such a comprehensive way would, however, be normally quite protracted in time. The possibility of appeal before the Courts ensures the legality of the decisions taken but reduces considerably the ability for quick responses to urgent matters.

The 2002 sector specific regime for electronic communications, in contrast to the ONP rules, being based on competition law methodology is equally hard to implement since it involves a full-scale market analysis, which is further to be conducted on a forward-looking basis. Nevertheless, it could be submitted that the new sectoral regime finds a middle way between classical specific rules and competition law in that it provides an in-depth analysis of the sector, while also applying a clear set of rules on an ongoing basis.

\subsubsection{REACTIVE VERSUS PRO-ACTIVE NATURE}

Generally, competition authorities determine whether certain behaviour is abusive on an $e x$ post basis (excluding mergers and acquisitions where an ex ante analysis is conducted). ${ }^{33}$ The rationale for this reactive nature of competition law is the presumption that actual and potential rivalry between undertakings exists and naturally sustains competition on the markets. Antitrust authorities intervene only when this competition is in some manner distorted, restricted or prevented.

In contrast to antitrust interventions, which are undertaken in response to evidence of banned anti-competitive behaviour, sector specific rules are applied ex ante, i.e. before any concrete evidence of harmful events. Sectoral rules normally define a narrow range of acceptable conduct and as Theon Van Dijk notes in this regard, "[b]y setting out the range of acceptable conduct in great detail in advance, a well-functioning set of sector specific rules can provide considerable certainty to the regulated utilities". ${ }^{44}$ Although this is true, one should not forget that the existence of sectoral rules does not preclude (at least in the Community legal order ${ }^{35}$ ) the application of competition rules and thus abiding the sector specific regime is by no means an excuse for abusive practices under general competition law.

\footnotetext{
${ }_{33}$ There are indeed a number of seminal decisions taken on an ex ante basis especially notifications to obtain exemption under Article 81(3) EC or clearance under the Merger Control Regulation. Important breakthrough cases taken on an ex ante basis in the field of EC communications law were e.g. the WorldCom decisions (Decision 1999/287 of 8 July 1998, Case IV/M.1069, WorldCom/MCI, OJ L 116/1, 4 May 1999 and Decision 2003/790 of 28 June 2000, Case IV/M.1741, MCI WorldCom/Sprint, OJ L 300/1, 18 November 2003. The latter cases remain, however, out of the scope of the present analysis since the latter concentrates on Article 82 rules and cases. For a critique of the ex post - ex ante comparison, see PIERRE LAROUCHE, "A Closer Look at Some Assumptions Underlying EC Regulation of Electronic Communications" (2002) Journal of Network Industries, Vol. 3, pp. 129-149, at pp. 130-135.

34 THEON VAN DIJK, supra note 22, at p. 96.

${ }^{35}$ In some legal orders the relationship lex specialis - lex generalis is decisive and the sector specific rules prevail over the general competition rules. Such is the case, for instance, under Swiss Law. See CHRISTOPH BEAT GRABER, “'The Lost Highway' Bleibt KMU der Zugang zur Breitbandkommunikation verbaut? Wege zur Marktöffnung nach schweizerischem und internationalem Recht" in DANIEL GIRSBERGER and JÖRG SCHMID (eds.), Rechtsfragen rund um die KMU, Zurich: Schulthess, 2003, pp. 217 et seq.
} 
Furthermore, as far as the sector specific rules within the 2002 regulatory framework are concerned, one should note that the distinction between ex post and ex ante is not as rigid as before. The National Regulatory Authorities (hereinafter NRAs) will have to conduct market definition and market analysis based on competition law methodology and although the analysis should be forward-looking, the authorities will undoubtedly take account of past and present facts and behaviour ${ }^{36}$ and in a way "wait for the market to provide an indication that intervention is necessary before they act". ${ }^{37}$ The initial procedure of market selection conducted by the Commission within the new market definition process is likewise based on observations of existing problematic situations and thus present and/or likely distortions and restrictions of competition.

Indubitably, the pro-active nature of sectoral regulation provides a better position for remedying knotty situations by addressing them before an actual abuse occurs. As we shall see below, this could be crucial for the promotion of competition in the electronic communications sector (in handling, for instance, complex access issues). There is, however, a certain danger stemming from the pro-activity of sectoral rules. The latter might be influenced by "wrong" policy choices and promote competition with anti-competitive means or simply continue to apply when intervention is no longer needed. ${ }^{38}$ In fact, even "good" policy choices might lead to dubious long-term outcomes. In particular, in a sector such as electronic communications, marked by network externalities, the market might settle at an inferior standard or reach unsatisfactory level of development of competition, failing to realise full economies of scale. Finally in the context of pro-activity, it should be noted that the implementation of the ex ante analysis might be particularly difficult in communications markets if there is a lack of data or turbulent developments. ${ }^{39}$

\subsubsection{TO PROTECT VERSUS TO PROMOTE OR RESTRICT COMPETITION}

Generic competition rules focus primarily on the protection of competition by identifying and rectifying behaviour leading to distortion, prevention or restriction of competition. Competition law has thus limited powers to impose controls, which substitute for competition where competition is either impossible or sub-optimal. ${ }^{40}$ The latter impotence of generic

36 The Commission Guidelines on market analysis and the assessment of significant market power under the Community regulatory framework for electronic communications networks and services (OJ C 165/6, 11 July 2002) state in that context at para. 20 that, "[i]n carrying out the market analysis under the terms of Article 16 of the Framework Directive, NRAs will conduct a forward looking, structural evaluation of the relevant market, based on existing market conditions. NRAs should determine whether the market is prospectively competitive, and thus whether any lack of effective competition is durable, by taking into account expected or foreseeable market developments over the course of a reasonable period. The actual period used should reflect the specific characteristics of the market and the expected timing for the next review of the relevant market by the NRA. NRAs should take past data into account in their analysis when such data are relevant to the developments in that market in the foreseeable future" (footnote omitted; emphasis added).

37 PIERRE LAROUCHE, supra note 33, at p. 132.

38 See e.g. JON STERN, “Regulatory Forbearance: Why Did OFTEL Find It So Hard?" (2004) Telecommunications Policy, Vol. 28, pp. 273-294.

39 See e.g. Commission Guidelines on market analysis and the assessment of significant market power, supra note 36 , at para. 70 .

40 THEON VAN DIJK, supra note 22, at p. 96. 
competition rules is precisely the reason for designing sector specific regimes. ${ }^{41}$ Sectoral rules allow interventions that go beyond the normal protection of competition ${ }^{42}$ and could actively promote it. In that sense, they embody concrete policy choices directed at certain markets and could lead through asymmetrical regulation to a relatively swift transition to competition. The downside of the latter policy is that as market forces develop, the imposed obligations might become unreasonably heavy and/or lead to negative outcomes (e.g. cross-subsidisation or cream-skimming).

\subsubsection{ONE-OFF INTERVENTIONS VERSUS LONG-TERM PERSPECTIVE}

Competition law intervention, as mentioned above, is meant to restore the inherently competitive market conditions. The initial position being notabene that such competitive conditions exist. The interventions are then intended to be one-off events with regard to a particular constellation of facts. This approach is well-suited for markets where the need for supervision is sporadic in the sense of "punishing" anti-competitive practices and bringing things "back to normal". The interventions set further a pattern as to how prevention, distortion or restriction of competition are interpreted and addressed.

The sectoral provisions function in a different way. They set out in (relatively) stable terms rules that apply for a (relatively) long time until a certain goal is achieved. An example in point is the ONP framework that managed the transition, together with the liberalisation Directives, from monopoly to competitive markets in European telecommunications. Relying on a detailed framework in a transition environment reduces uncertainty and allows for making long-term commitments and investments that are critical for the success of the very transition. Under the 2002 regulatory package, which has the purpose to sustain the achieved level of competition in communications and promote it, the NRAs are equally required to supervise the markets regularly, on an ongoing basis, rather than to intervene sporadically when distortion occurs.

\subsubsection{NARROWLy FocUSED OBJECTIVES VERSUS BROAD RANGE OF OBJECTIVES}

Competition is believed to ensure consumer welfare, which involves allocative, productive and dynamic efficiencies. The objective of competition law in that sense could be broadly defined as protection of that competition. As stated in the EC Treaty, the Community competition law is a "system ensuring that competition in the internal market is not

\footnotetext{
${ }^{41}$ Commission Recommendation of 11 February 2002 on relevant product and service markets within the electronic communications sector susceptible to ex ante regulation in accordance with Directive 2002/21/EC of the European Parliament and of the Council on a common regulatory framework for electronic communication networks and services, OJ L 114/45, 8 May 2003 (hereinafter the Relevant Market Recommendation).

42 The Access Notice (Commission Notice on the application of the competition rules to access agreements in the telecommunications sector, OJ C 265/3, 22 August 1998), for instance, states at para. 15 in that regard that, "[i]t is important to note that the ONP Directives impose on TOs having significant market power certain obligations of transparency and nondiscrimination that go beyond those that would normally be imposed under Article 86 of the Treaty [now Article 82 EC]" (emphasis added).
} 
distorted". ${ }^{43}$ Thus, the EC competition rules (and accordingly the national competition laws) focus on the prohibition of agreements that prevent, restrict or distort competition (as enshrined in Article $81 \mathrm{EC}$ ) and on conduct constituting an abuse of dominant position (as enshrined in Article 82 EC). In fulfilling their so-defined tasks, the national and the Community competition authorities achieve in fact a wide variety of economic and societal goals. Nevertheless, in fulfilling these tasks under competition law, authorities are to concentrate only on the protection of competition in economic sense. Indeed, it is very important that the objectives of competition law remain so narrowly defined. In the converse situation, the legitimacy of the law would be questioned and politics would interfere to the achievement of broader set of objectives. ${ }^{44}$

Sector specific regulation, on the other hand, could legitimately be intended to achieve precisely the latter broader objectives. This allows regulators to stray from the pure competition law rationale and focus on broader efficiency/welfare criteria in order to promote competition in the long-term. Additionally, the regulation of a specific industry can be used to pursue other extraneous policy goals, such as societal and distributional ones. ${ }^{45}$ "The associated risk is that a set of broad (and possibly conflicting) objectives provides scope for unpredictable and discretionary interventions, thus causing regulatory uncertainty". ${ }^{46}$ The danger of regulatory capture ${ }^{47}$ in view of the possibility of pursuing other goals needs also to be accounted for. This danger is particularly portentous in communications being a network industry, where the opportunity of tipping markets and earning monopoly profits encourages lobbying. In contrast to the sectoral agencies, "[u]ndue influence by the industry over the competition authorities is less likely because they are not in continuous contact with any one sector". ${ }^{48}$ Consequently, if sector specific rules are to be reviewed within a certain period of time, "[s]uch a review process should be carried out by an economy-wide body rather than

${ }^{43}$ Article 3(1)(g) of the EC Treaty.

${ }^{44}$ See Damien Neven, "Working Paper on Competition Policy Objectives" in Claus Dieter Ehlermann and LaRaine L. LAUdATI (eds.), European Competition Law Annual 1997: Objectives of Competition Policy, Oxford/Portland, Oregon: Hart Publishing, 1998, at pp. 111-112. See also LAWrenCE J. SPIWAK, “Antitrust, the 'Public Interest' and Competition Policy: The Search for Meaningful Definition in a Sea of Analytical Rhetoric" (1997) Antitrust Report, pp. 2-23.

${ }^{45}$ Cave and Crowther confirm this reasoning. They point out that, "[t]he competitive process is relied upon to provide goods and services at acceptable conditions of price and quality, with only a relatively minimal intervention to correct specific market failures. 'Traditional' regulation, on the other hand has been employed to achieve specifically defined social and political objectives, for instance to impose universal service obligations". See MARTIN CAVE and PETER CROWTHER, "Regulating Interconnection Charges from a Competition Law Perspective“, Conference Paper, ITS 11 th Biennial Conference, Seville, 1996, as referred to by MARC BOURREAU and PINAR DOĞAN, "Regulation and Innovation in the Telecommunications Industry" (2001) Telecommunications Policy, Vol. 25, pp. 167-184, at p. 170.

46 THEON VAN DIJK, supra note 22, at p. 98.

47 "Regulatory capture" stresses the fact that industries can influence policy makers in taking decisions in their interests rather in those of society. "Regulatory capture" was one of the concepts used by the Chicago School as an argument against government intervention. See e.g. GEORGE J. STIGLER, "The Theory of Economic Regulation" (1971) Bell Journal of Economic and Management Science, Vol. 2, pp. 3-21 and RichARD A. POSNER, "Theories of Economic Regulation" (1974) Bell Journal of Economics and Management Science, Vol.5, pp.335-358. It should additionally be noted that regulatory capture has been a recurrent phenomenon throughout the history of telecommunications regulation. See also RAYMOND DE BONDT and PATRICK VAN CAYSEEle, "Government Policy Towards Industrial Innovation" (1985) Maandschrift Economie, Vol. 49, No 3, pp. 214-226, as referred to by PATRICK VAN CAYSEele and ROGER VAN DEN BERGH, "Antitrust Law" in BOUdewijn BOUCKAERT and GERRIT DE GEEST (eds.), Encyclopaedia of Law and Economics, Cheltenham, UK: Edward Elgar Publishing, 2000, pp. 467-497, at p. 470.

48 EUROPEAN COMMISSION, Liberalisation of Network Industries, supra note 22, at pp. 36-37. 
sector-specific agency whose raison d'être might depend on the very existence of such rules". ${ }^{49}$ In the same line of reasoning, definite sunset provisions regarding the powers of national regulatory authorities may be critical in "ensuring that regulation for the sake of regulation alone does not continue when no longer needed". ${ }^{50}$

\subsubsection{LIMITED INSTRUMENTS VERSUS BROAD RANGE OF INSTRUMENTS}

General competition authorities do not have a particularly sizeable toolkit for their interventions. The possibilities for designing a specific remedy for a specific problem are limited. On the one hand, by the formal constraint of competition law legislation and on the other hand, partly due to the restricted potential to process complex industry-specific information needed for detailed remedies. Moreover, sectoral rules could go beyond the limitations of a certain case and regulate re-occurring situations in a consistent manner assuring long-term remedy of thorny issues. ${ }^{51}$

Being, as discussed above, often intended for the achievement of broader objectives and allowing for imposing obligations that could go beyond those normally imposed under competition law, sector specific instruments could be designed and targeted at a specific problem. ${ }^{52}$ Sectoral agencies' know-how of the communications industry and the characteristics of the national market in question could further contribute to finding the right tools, behavioural and/or structural.

\subsubsection{ANTITRUST EXPERTISE VERSUS COMMUNICATIONS INDUSTRY EXPERTISE}

The NRAs entitled with the task of communications specific rules' application and the national competition authorities' (NCAs) application of the domestic and Community antitrust rules at Member State level differ in a number of ways. Most noteworthy in the context of our present discussion, is the divergence of their expertise. Due to their sectoral focus, NRAs hold naturally superior knowledge with regard to the mechanisms of the industry and to the firms active in the diverse communications markets. NRAs have full understanding of the specificities of electronic communications networks and services in the sense of network effects, economies of scale and scope, innovation, dynamism, new and emerging markets, and possible convergence implications. ${ }^{53}$ They have the means, the developed methodology and the communications specific know-how enabling them to gather

\footnotetext{
49 DAMIEN GERADIN and Michel KeRF, supra note 22, at p. 338.

${ }^{50}$ MARK NAFTEL and LaWrenCE J. SPIWAK, The Telecoms Trade War: The United States, the European Union and the World Trade Organization, Oxford/Portland, Oregon: Hart Publishing, 2000, at p. 360.

${ }^{51}$ An example in point could be the unbundling of the local loop whereby by sector specific rules assured access to the local markets held by the former public telecommunications operators. See Regulation 2887/2000/EC of the European Parliament and of the Council of 18 December 2000 on unbundled access to the local loop, OJ L 336/4, 30 December 2000.

52 For some examples on the limitations of general competition rules versus sectoral ones regarding number portability; retail price control for residential customers; network charge control; interconnection obligations; and price control over mobile termination rates, see EDWARD PITT, "Competition Law in Telecommunications" in IAN WALDEN and JOHN ANGEL (eds.), Telecommunications Law, London: Blackstone Press, 2001, pp. 249-278, at pp. 265-268.

53 ARLAN GATES, "Convergence and Competition: Technological Change, Industry Concentration and Competition Policy in the Telecommunications Sector" (2000) University of Toronto Faculty of Law Review, Vol. 58, Issue 2, pp. 83-120, at p. 94.
} 
and process data critical for any further analyses and the design of regulatory intervention. If the NCAs are endowed with the task of supervising the communications markets, the detection of anti-competitive behaviour may be obstructed due to the restricted information that these institutions hold. ${ }^{54}$ Due to the sporadic nature of interventions of the competition authorities, it would be further difficult for them to build up the necessary communications expertise, even in a longer period of time..$^{55}$

On the other hand, the antitrust agencies have superior experience in dealing with typical competition law situations and applying the Treaty's competition rules and those developed through the practice of the European Court of Justice and the Court of First Instance. Elaborate analytical exercises, such as product/services and geographical market definitions through application of the SSNIP test, market analyses and application of complex dominance concepts, belong very much to the everyday job of the competition authorities. Consequently, once detected, the anti-competitive behaviour would be better assessed by the NCAs and the concrete intervention could be more adequate. This could additionally feed positively back to the legal certainty (for the communications market players) and to the continuity of antitrust law and practice in general. Being active in all sectors of the economy, the NCAs could also utilise cross-sectoral experience when faced with new situations and respond more flexibly to these than the overly specialised NRAs. Especially as network industries are concerned, the NCAs could use the valuable experience gathered in markets with more advanced competition (e.g. communications) and transfer it to other network sectors (e.g. electricity or post).

With the transformation of the EC telecommunications regime, the differences in expertise are made in fact more pronounced and the potential ramifications of these are aggravated. This submission is true since under the 2002 Community communications regime, the sector specific rules are aligned with the traditional EC antitrust methodology. While under the "old" framework, NRAs simply had to apply the rules, as identified in the ONP Directives, with little possibility for deviation, now they are to carry out the complex tasks of full-scale market definition, market analysis and remedies' design. While the current alignment of sectoral regulation with competition law formulae and thus, with economic rationales, is largely a positive development, it does entail certain dangers. Martin Cave and Pierre Larouche have stressed these in the particular context of the application of the SSNIP test, noting that, "[w]hile this approach is conceptually helpful, it is difficult to apply in practice, particularly across 15 markets". 56

\footnotetext{
${ }^{54}$ MARC BOURREAU and PINAR DOĞAN, supra note 45, at p. 170. Geradin and Kerf summarise their analysis in that regard, noting that, "[a]ntitrust authorities and courts should not be relied upon to take decisions on untested, complex, telecommunications-specific issues, on the basis of general antitrust rules. The fact that those authorities tend to intervene ex post, that judicial proceedings are likely to be long, and that contradictory decisions may be taken by different bodies is likely to raise uncertainty to unacceptable levels“. See DAMIEN GERADIN and MICHEL KERF, supra note 22, at p. 341.

55 EUROPEAN COMMISSION, Liberalisation of Network Industries, supra note 22, at p. 36.

${ }^{56}$ Martin CAVE and PIERRE LAROUCHE (Rapporteurs), "European Communications at the Crossroads", Report of the CEPS (Centre for European Policy Studies) Working Party on Electronic Communications, Brussels: Centre for European Policy Studies, October 2001, at p. 7.
} 
The simple fact that the NCAs apply the Community's law for over forty years now is also not to be underestimated. Throughout this considerable period of time, they have developed certain sensitivity for the European mechanisms and strengthened the relationships with the other EC institutions, most notably the European Commission and the Courts.

\section{CONCLUSIONS}

Considering the foregoing comparison between competition law and sector specific rules, it could be safely concluded that there are certain pros and cons inherent to both sets of instruments. The benefits associated with sectoral rules boil down mainly to their potential for accounting for sector specific economic and technological factors and for designing detailed regulatory interventions aiming precisely and efficiently at a certain problem. Sectoral regulation comprises in that sense a more elaborate and targeted set of provisions, which embodies more clearly pronounced policy choices. Where competition has not yet advanced, sector specific rules can actively promote its development and/or additionally foster the achievement of wider societal objectives. Equally, where the barriers of entry are extremely high and/or markets exhibit network effects or other natural monopoly characteristics, sectoral rules could address and surmount these more effectively than general competition law. Most notably, they could also tackle situations stemming not only from dominance.

On the other hand, the asymmetric treatment inherent to sector specific regulation could distort the natural development of competitive markets preventing efficient undertakings' responses to evolving competition. Furthermore, the extraneous policy concerns may seriously reduce efficiency and allow for regulatory capture. Sectoral rules can also be quite rigid in the face of rapid technological and market developments and may, due to regulatory inertia, sometimes continue to apply without proper justification. ${ }^{57}$

In contrast, competition law could be fairly flexible to new situations. Competition rules have the advantages of a legal system focused on a narrow range of objectives, applied according to a set procedure and built upon a multitude of precedents. Competition rules are, however, hardly capable of swift and/or tailored remedies to urgent problems. Their reactive nature could additionally mean that even where competition is in principle able to develop, there could be considerable time delays before competition is actually achieved. A textbook example in this regard is the liberalisation of the New Zealand's telecommunications market. The light-handed approach chosen by New Zealand and based predominantly on competition rules failed to address properly the transition from monopoly to competition, led to lengthy lawsuits ${ }^{58}$ and slowed substantially the access of new communications providers. ${ }^{59}$

\footnotetext{
57 As Naftel and Spiwak eloquently state, "[a]uthorising regulators to forebear from regulations is a sound policy, but one that regulators are loath to follow". See MARK NAFTEL and LAWRENCE J. SPIWAK, supra note 50, at p. 350. The authors prove their submission with an example of the US telecommunications regulation. The FCC was granted power under the 1996 Telecommunications Act to forebear from regulating in an area where it had certain authority, but there were no visible actual abdications from authority.

58 See Telecom Corporation of New Zealand Ltd v. Clear Communications Ltd [1995] 1 NZLR 385.
} 
The costs associated with both sets of regulatory tools do not point to an unequivocal finding either: Deregulation will normally reduce or eliminate the administrative costs related to traditional rate-of-return and incentive regulation, as well as the costs associated with the specific regulator's staff. ${ }^{60}$ Entrusting the economic regulation of telecommunications (and possibly other network industries) to an economy-wide regulatory body could be then an overall cost-reducing factor. Sectoral authorities, however, should not necessarily be perceived as an overly expensive undertaking. Entrusting specialised authorities with the regulatory task, while "limiting judicial processes to appeals on legal grounds only, limiting the number of sector-specific rules and keeping them as simple as possible, discouraging delaying tactics, streamlining procedures and adopting time-limits", ${ }^{61}$ can in fact lead to a reduction of the length and costs of regulatory processes. ${ }^{62}$

Thus again, the reiterated conclusion is that certain advantages and disadvantages could be found in the application of both sectoral and competition law rules. A derivative conclusion in the general context of regulatory tools is that it is perhaps more sensible to approach the two sets of instruments not necessarily as opposing and exclusionary but rather as complementary. The latter approach will allow using both tools for different situations beyond the rhetoric of regulation against deregulation. ${ }^{63}$ Without the misleading labelling of "bad" or "good", both instruments could be used in hybrid regulatory models to the achievement of the pursued goals. Bourreau and Doğan confirm this mixed approach with specific regard to innovation. They acknowledge that, "[e]ither of the two mechanisms [sector specific or competition rules] may provide a more efficient control depending on the relevant market structure. For example, one might think that the flexible nature of ex post measures stimulates the incentives to innovate, and hence should be used for the new markets in which the ultimate aim is to promote market growth and the incumbent has no important dominance. On the other hand, a stricter control by ex ante regulation may be more suitable for the old markets in which abuse of the dominant position by the incumbent should not be tolerated even for the sake of higher market growth". ${ }^{4}$

\footnotetext{
${ }^{59}$ See TheOn VAN DijK, supra note 22, at p. 101; MAlcolm WebB and MARTYN TAYLOR, "Light-Handed Regulation of Telecommunications in New Zealand: Is Generic Competition Law Sufficient?“ (1999) International Journal of Communications Law and Policy, Issue 2; DAMIEN GERADIN and Michel KeRF, supra note 22, at pp. 119-162.

${ }^{60}$ J. GREGory SidAK and DANIEl F. SPUlBer, "Deregulation and Managed Competition in Network Industries" (1998) Yale Journal on Regulation, Vol. 15, No 1, pp. 117-147, at p. 121.

${ }^{61}$ DAMIEN GERADIN and Michel KeRF, supra note 22, at p. 350.

62 Ibid. at pp. 347 et seq.

${ }^{63}$ On the false assumptions of regulation, see PIERRE LAROUCHE, supra note 37, at pp. 134-135.

${ }^{64}$ MARC BOURREAU and PINAR DOĞAN, supra note 45, at p. 170.
} 